\title{
Professional work and learning with smartphones: a comparative study of school librarians from Australia, Hong Kong and United Kingdom
}

\author{
Zvjezdana Dukic \\ Department of Information Sciences, University of Zagreb \\ Ivana Lučića 3, 10000 Zagreb \\ Croatia \\ dana.dukic@gmail.com
}

Annie Tam

The ISF Academy, Hong Kong

No.1, Kong Sin Wan Road, Pokfulam,

Hong Kong

atam@isf.edu.hk

\begin{abstract}
The study explores the role of mobile technologies in school librarians' daily work and professional learning and development. The aim of the study is to examine

how school librarians search, access, use and share information via their smartphones, what smartphone functionalities they use for these purposes, and what apps and social media are most frequently used. The study is based on empirical research conducted on a sample of school librarians/teacher librarians in Australia, Hong Kong and United Kingdom. Data were collected with online survey. The major finding of this study is that school librarians in Australia and Hong Kong widely use smartphone technologies for their daily needs and for professional work and learning. Various smartphone functionalities tools are used to satisfy these varied needs. Also school librarians from Hong Kong use various smartphone functionalities more frequently than study participants from Australia and UK. Barriers to smartphone use are also discussed but it seems that they do not detract school librarians from using smartphone technologies for their daily professional activities.
\end{abstract}

Keywords: smartphones, daily use, professional use, school librarians

\section{Introduction}


Smartphones have greatly improved how people communicate, learn, and live in the digital age. In library and information science there is much current research on provision of mobile library services to users but very few studies look at use of smartphone technologies by librarians for their own professional work and learning.

One would assume that librarians, being highly engaged in exploring various opportunities for providing mobile access to library resources and offering services adjusted to mobile users, would be particularly strong in their capacity to apply mobile technologies to their own professional work and learning. The aim of this study is to explore the role of smartphones in school librarians' daily professional activities and their endeavors to keep up with new developments in the library profession. Furthermore the study tries to find out what smartphone applications and functionalities school librarians/teacher librarians commonly use to meet their daily professional needs.

\section{Related literature}

There is an extensive research literature on learning with smartphones with most studies situated in the context of formal education. Hwang and Tsai (2011) in their meta-analysis of research trends in mobile learning found that most studies investigated mobile learning in higher education, elementary and high schools while very few studies focused on working adults' smartphone use for their professional purposes. Studies looking at smartphone use for professional work and learning can be found in medical areas of practice and these studies show that smartphones are widely accepted among healthcare providers in their daily workflow and clinical decision-making (O'Connor, 2010; Franko and Tirrell, 2012; Johnson et al., 2015). In the library and information science domain studies of smartphone use for learning and professional purposes mostly focus on exploring the potential of smartphones for delivering library services, development and promotion of mobile services to library users and users' acceptance of mobile library services (Dresselhaus \& Shrode, 2012; Bomhold, 2013; Pazur, 2014; Wu et al., 2014). These studies commonly discuss mobile learning issues from the perspective of library users and do not tackle librarians' perspective. In recent research on smartphone use for professional and learning purposes there are two studies worth mentioning because they both focus specifically on professional librarians and LIS students. Aharony (2013) explored librarians' and LIS students' perspectives toward mobile libraries by applying Technology Acceptance Model (TAM). The study found that LIS students showed more interest in using their mobile devices to access library sources and services than librarians. Another study (Dukic, Chiu \& Lo, 2015) involves Library and Information Science part-time postgraduate students from Hong Kong and Japan, most of them working in libraries and it shows that research participants find smartphones very useful for their academic learning and that they use smartphones regularly for study purposes. Recent studies of mobile learning also indicate that social media are frequently accessed 
with smartphones not only for socializing and entertainment but also for learning purposes (Gikas and Grant, 2013; Murphy, Farley, Lane, Hafeez-Baig and Carter, 2014).

Since there are no studies looking at school librarians smartphone use for professional work and learning it is expected that this research would fill this knowledge gap and provide a useful insight in school librarians' smartphone professional usage.

\section{Research questions}

The main goal of this study is to find out whether school librarians from Hong Kong, Australia and United Kingdom use smartphones for professional work and learning purposes, to explore what specific smartphone applications and functionalities they use and to identify probable barriers to smartphone use for professional purposes. The following research questions are addressed:

- How do school librarians use their smartphones for their daily needs?

- Do school librarians use mobile phones/smartphones for professional work and learning?

- What smartphone applications and functionalities do school librarians apply to meet their daily professional needs?

- What are possible barriers to school librarians' smartphones use for professional purposes?

- Do school librarians from Australia, Hong Kong and United Kingdom differ in frequency and ways of using mobile phones or smartphones for professional work and learning?

\section{Methods}

This is an exploratory research and the research method is survey. Data were collected with an online questionnaire. The questionnaire included seventeen questions, fifteen closedended questions and two open-ended questions organized in three sections. First section included some basic information such as gender, age, and type of library, second section was about habits of smartphone use for everyday needs while third section was asking about frequency in performing various work related activities such as browsing, reading, searching, collaborating, using productivity tools and recording. This last section included also a question about possible barriers in smartphone use for professional purposes.

The research was conducted on school librarians working in primary or secondary schools in Hong Kong, Australia and United Kingdom. The questionnaire was created with SurveyMonkey and the link to the questionnaire was distributed to school librarians through 
their professional associations on Yahoo! Groups platform. It is important to mention that participants from Hong Kong are school librarians employed in international, English speaking schools. Participation in this research was voluntary and the questionnaire guaranteed anonymity to all participants. Data were collected during the winter term of 2014 . Fifty-six valid responses were received from Hong Kong, fifty from Australia and forty-four from United Kingdom.

All questions about frequency of smartphone use for performing various activities included Likert scale with five options for respondents: daily, weekly, monthly, less than monthly or never. Since this paper is focused on activities with smartphones preformed regularly, only data about daily and weekly smartphone use are included. Collected data were analyzed by applying simple descriptive statistics.

\section{Findings and discussion}

\section{Sample description}

In all three samples the vast majority of respondents are female school librarians. Regarding the age category Hong Kong respondents are visibly younger than Australian and UK respondents. In all three samples there are more school librarians working in secondary schools than in primary schools while in Australian sample there is a high percentage of school librarians working in K12 schools.

Table 1: Gender, age and type of school library

\begin{tabular}{|l|l|c|c|c|}
\hline & & Australia & Hong Kong & UK \\
\hline \multirow{3}{*}{ Gender } & Male & $8 \%$ & $16 \%$ & $2 \%$ \\
\cline { 2 - 5 } & Female & $92 \%$ & $84 \%$ & $98 \%$ \\
\hline \multirow{4}{*}{ Age } & 19 and below & 0 & $4 \%$ & 0 \\
\cline { 2 - 5 } & $20-30$ & $2 \%$ & $13 \%$ & $13 \%$ \\
\cline { 2 - 5 } & $31-40$ & $16 \%$ & $23 \%$ & $16 \%$ \\
\cline { 2 - 5 } & $41-50$ & $22 \%$ & $39 \%$ & $14 \%$ \\
\cline { 2 - 5 } & 51 and above & $60 \%$ & $21 \%$ & $57 \%$ \\
\hline \multirow{3}{*}{$\begin{array}{l}\text { Library } \\
\text { type }\end{array}$} & Primary school library & $24 \%$ & $34 \%$ & $7 \%$ \\
\cline { 2 - 5 } & Secondary school library & $44 \%$ & $43 \%$ & $88 \%$ \\
\cline { 2 - 5 } & K12 school & $32 \%$ & $23 \%$ & $5 \%$ \\
\hline
\end{tabular}

\section{Smartphone use for everyday needs}


The purpose of the question about school librarians' smartphone use for daily needs was to provide an overview of participants' overall smartphone acceptance. Data from Table 2 show that school librarians from Australia, Hong Kong and UK commonly use smartphones to keep contact with friends and family, search for information, and socialize through social networking websites. Use of various productivity tools such as calendar, note-taking tools and to-do-list is also popular and frequently used by participants in all three samples. A big difference in frequency of smartphone use between the three samples can be seen in casual reading. A popularity of casual reading with smartphones among Hong Kong school librarians can be partly explained with findings from the study by Dukic et al. (2015) showing that participants from Hong Kong often read Japanese comics on their smartphones. School librarians from Hong Kong use their smartphones more often than others for professional reading and accessing libraries. Using smartphones for playing games, listening to the music and watching movies and TV series is also more popular among Hong Kong school librarians. Based on data from Table 2 it can be concluded that generally school librarians from Hong Kong perform various daily activities with smartphones more frequently than school librarians from Australia and UK. An explanation for this difference in smartphone activity might be the younger age of the Hong Kong sample, since studies about mobile technology indicate that age plays a role in mobile technology acceptance (Wang et al., 2009).

Table 2: Smartphone use for daily needs

\begin{tabular}{|l|c|c|c|}
\hline \multicolumn{1}{|c|}{ Types of activities performed daily or weekly } & Australia & Hong Kong & UK \\
\hline $\begin{array}{l}\text { Communicate with friends \& family (e.g. email, SMS, } \\
\text { chat) }\end{array}$ & $96 \%$ & $96 \%$ & $93 \%$ \\
\hline Use search engines (e.g. Google, Yahoo, Baidu) & $78 \%$ & $87 \%$ & $74 \%$ \\
\hline $\begin{array}{l}\text { Social activities with social media (e.g. Facebook, } \\
\text { Twitter) }\end{array}$ & $75 \%$ & $77 \%$ & $76 \%$ \\
\hline Finance and banking & $31 \%$ & $26 \%$ & $22 \%$ \\
\hline Games, music, movies, TV series, etc. & $36 \%$ & $48 \%$ & $29 \%$ \\
\hline $\begin{array}{l}\text { Using productivity tools (e.g. calendar, note-taking } \\
\text { tools, to-do lists) }\end{array}$ & $64 \%$ & $85 \%$ & $70 \%$ \\
\hline Finding locations, like streets, restaurants etc. & $46 \%$ & $54 \%$ & $41 \%$ \\
\hline $\begin{array}{l}\text { Accessing reference sources (e.g. encyclopaedia, } \\
\text { dictionary) }\end{array}$ & $39 \%$ & $46 \%$ & $29 \%$ \\
\hline Hobbies, sports, fitness, travel & $34 \%$ & $38 \%$ & $29 \%$ \\
\hline $\begin{array}{l}\text { Casual reading: books, comics, magazines, } \\
\text { newspapers, etc. }\end{array}$ & $32 \%$ & $71 \%$ & $29 \%$ \\
\hline $\begin{array}{l}\text { Professional reading: articles, e-books, blogs, } \\
\text { websites }\end{array}$ & $33 \%$ & $57 \%$ & $30 \%$ \\
\hline Access libraries (e.g. public library, school library) & $26 \%$ & $37 \%$ & $18 \%$ \\
\hline
\end{tabular}

Professional work and learning activities with smartphones 
Activities with smartphones meeting school librarians' daily professional work and learning needs are observed through five major categories:

1. Professional communication (talking, texting, sending email, posting)

2. Browsing, reading, viewing or listening

3. Accessing information and doing searches

4. Using productivity tools

5. Recording and making photos, audio, video or multimedia materials

\section{Professional communication (talking, texting, sending email, posting)}

School librarians from all three locations often use smartphones to discuss professional issues by talking on the phone, sending email, SMS, MMS or using chat applications (Table 3). Further, school librarians from UK more often post to social networking sites whereas school librarians from Australia and Hong Kong more often send photos to these websites. Table 3 shows that posting to the school learning platform is performed only by school librarians from Australia and Hong Kong, and absence of data for UK librarians might be explained by different roles of school librarians in researched geographical locations. Overall, school librarians from Hong Kong are more active from others in almost all activities related to communication with smartphones for professional purposes.

Table 3: Smartphone use for professional communication and sharing

\begin{tabular}{|l|c|c|c|}
\hline \multicolumn{1}{|c|}{ Activities performed daily or weekly } & Australia & Hong Kong & UK \\
\hline $\begin{array}{l}\text { Talk by phone to colleagues to discuss professional } \\
\text { issues }\end{array}$ & $31 \%$ & $49 \%$ & $38 \%$ \\
\hline Send emails to colleagues and professional groups & $33 \%$ & $45 \%$ & $40 \%$ \\
\hline $\begin{array}{l}\text { Use SMS, MMS or chat apps to discuss professional } \\
\text { issues }\end{array}$ & $28 \%$ & $49 \%$ & $30 \%$ \\
\hline $\begin{array}{l}\text { Post or comment professional issues to social } \\
\text { networking sites (e.g. Facebook, Twitter) }\end{array}$ & $23 \%$ & $23 \%$ & $37 \%$ \\
\hline $\begin{array}{l}\text { Send photos/videos from smartphone to social } \\
\text { networks }\end{array}$ & $31 \%$ & $47 \%$ & $17 \%$ \\
\hline Post to the school learning platform (e.g. Moodle) & $10 \%$ & $13 \%$ & 0 \\
\hline
\end{tabular}

\section{Browsing, reading, viewing or listening}

The findings from the study show that many school librarians from all three locations regularly browse through various professional websites with their smartphones (Table 4). It is interesting that the most popular activity among school librarians from all three locations is 
browsing and reading materials on professional social networking sites. Social bookmarking websites and social media like YouTube are also popular. School librarians from Hong Kong more often than others access and read materials stored in cloud (e.g. Dropbox, Box). Reading professional journals, magazines and e-books is least popular in all three samples.

Table 4: Smartphone use for browsing, reading, viewing and listening for professional purposes

\begin{tabular}{|l|c|c|c|}
\hline \multicolumn{1}{|c|}{ Activities performed daily or weekly } & Australia & Hong Kong & UK \\
\hline $\begin{array}{l}\text { Browse/read professional websites, blogs, } \\
\text { wikis, micro-blogs etc. }\end{array}$ & $34 \%$ & $68 \%$ & $30 \%$ \\
\hline $\begin{array}{l}\text { Browse/read posts on professional social } \\
\text { networking sites (e.g. Facebook) }\end{array}$ & $63 \%$ & $76 \%$ & $53 \%$ \\
\hline $\begin{array}{l}\text { Browse social bookmarking sites (e.g. } \\
\text { Delicious, Pinterest) }\end{array}$ & $44 \%$ & $30 \%$ & $27 \%$ \\
\hline $\begin{array}{l}\text { View a video clip (from YouTube, TED talks } \\
\text { or similar) }\end{array}$ & $39 \%$ & $59 \%$ & $23 \%$ \\
\hline $\begin{array}{l}\text { Read articles from professional journals \& } \\
\text { magazines }\end{array}$ & $18 \%$ & $23 \%$ & $10 \%$ \\
\hline Read e-books & $18 \%$ & $13 \%$ & $20 \%$ \\
\hline $\begin{array}{l}\text { Access/read documents from cloud storage } \\
\text { (Dropbox. Box etc.) }\end{array}$ & $18 \%$ & $38 \%$ & $20 \%$ \\
\hline
\end{tabular}

\section{Searching and accessing information}

Using smartphones to search for information with search engines is very popular among school librarians from all three locations. School librarians from Hong Kong more often than others search library catalogs and this finding is compatible with the result from Table 2 which shows that Hong Kong participants also more often than others access libraries with their smartphones. Data in Table 5 also show that Hong Kong school librarians access reference sources such as encyclopedias and dictionaries more often than Australian and UK respondents and this might be partly explained by the fact that respondents in Hong Kong sample are not all English native speakers and those with another mother tongue need to use dictionaries for translation purposes. Table 2 shows that study participants from Hong Kong more frequently than others search and access information with their smartphones for professional purposes.

Table 5: Searching and accessing information with smartphones for professional purposes

\begin{tabular}{|c|c|c|c|}
\hline Activities performed daily or weekly & Australia & Hong Kong & UK \\
\hline Search with search engines (e.g. Google, & $59 \%$ & $75 \%$ & $50 \%$ \\
\hline
\end{tabular}




\begin{tabular}{|l|c|c|c|}
\hline Yahoo) & & & \\
\hline Access and searching library catalogue & $13 \%$ & $30 \%$ & $13 \%$ \\
\hline Access and searching e-databases & $11 \%$ & $17 \%$ & $7 \%$ \\
\hline $\begin{array}{l}\text { Access reference sources (e.g. } \\
\text { encyclopaedia, dictionary) }\end{array}$ & $26 \%$ & $36 \%$ & $13 \%$ \\
\hline
\end{tabular}

\section{Using productivity tools}

Scheduling tools like calendars and organizers are particularly popular among all study participants. Note taking and memo tools are more popular among Australian and Hong Kong school librarians than among UK school librarians. Data from Table 6 show that school librarians from Hong Kong use productivity tool more often than others.

Table 6: Using smartphone productivity tools for professional purposes

\begin{tabular}{|l|c|c|c|}
\hline \multicolumn{1}{|c|}{ Activities performed daily or weekly } & Australia & Hong Kong & UK \\
\hline $\begin{array}{l}\text { Plan personal schedule (e.g. Google calendar, } \\
\text { organizers) }\end{array}$ & $47 \%$ & $72 \%$ & $48 \%$ \\
\hline $\begin{array}{l}\text { Make notes with note taking tools (e.g. } \\
\text { Evernote) }\end{array}$ & $37 \%$ & $42 \%$ & $17 \%$ \\
\hline $\begin{array}{l}\text { Create documents (e.g. text, presentation, } \\
\text { spread-sheets) }\end{array}$ & $13 \%$ & $19 \%$ & 0 \\
\hline
\end{tabular}

\section{Recording and making photos, audio, video or multimedia materials}

School librarians from all three regions often take photos with their smartphone to record learning materials (e.g. book displays, exhibitions). Other recording tools on smartphone are rarely used for professional purposes, although Hong Kong school librarians use these tools more frequently than others.

Table 7: Making and recording with smartphones for professional purposes

\begin{tabular}{|l|c|c|c|}
\hline \multicolumn{1}{|c|}{ Activities performed daily or weekly } & Australia & Hong Kong & UK \\
\hline $\begin{array}{l}\text { Take photos to record learning materials (e.g. } \\
\text { book displays, exhibitions) }\end{array}$ & $39 \%$ & $51 \%$ & $43 \%$ \\
\hline $\begin{array}{l}\text { Record audios/videos to create presentations, } \\
\text { teaching materials or professional events } \\
\text { record }\end{array}$ & $13 \%$ & $26 \%$ & $6 \%$ \\
\hline
\end{tabular}


School librarians from Australia, Hong Kong and UK frequently use smartphones for professional communication and sharing on social networking websites. This finding goes along with findings of other studies looking at engagement with smartphones in social networking (Gikas and Grant, 2013; Murphy et al, 2014). Table 8 shows that school librarians from Australia, Hong Kong and UK are all more active in browsing or reading than in posting. The most popular posting activity in all three samples is sending photos to social networking websites, but it is obvious that school librarians from Hong Kong and Australia are performing this activity with their smartphones much more frequently than school librarians from UK.

Table 8: Social media activities with smartphones for professional purposes

\begin{tabular}{|l|c|c|c|}
\hline \multicolumn{1}{|c|}{ Activities performed daily or weekly } & Australia & Hong Kong & UK \\
\hline $\begin{array}{l}\text { Browse/read posts on professional social } \\
\text { networks (e.g. Facebook) }\end{array}$ & $63 \%$ & $76 \%$ & $53 \%$ \\
\hline $\begin{array}{l}\text { Browse social bookmarking websites (e.g. } \\
\text { Delicious, Pinterest) }\end{array}$ & $44 \%$ & $30 \%$ & $27 \%$ \\
\hline $\begin{array}{l}\text { Browse school learning management } \\
\text { platform (e.g. Moodle) }\end{array}$ & $14 \%$ & $20 \%$ & 0 \\
\hline $\begin{array}{l}\text { Post to a blog, wiki, Facebook, micro-blog, } \\
\text { etc. }\end{array}$ & $23 \%$ & $23 \%$ & $37 \%$ \\
\hline $\begin{array}{l}\text { Post to school learning management } \\
\text { platform }\end{array}$ & $10 \%$ & $13 \%$ & 0 \\
\hline $\begin{array}{l}\text { Post professional contents to social } \\
\text { bookmarking sites }\end{array}$ & $31 \%$ & $47 \%$ & $17 \%$ \\
\hline $\begin{array}{l}\text { Send photos/videos from smartphone to } \\
\text { social networks }\end{array}$ & & $13 \%$ & $7 \%$ \\
\hline
\end{tabular}

\section{Barriers in using smartphone for professional needs}

Although school librarians on both locations widely use their smartphones for professional purposes it can be seen from Table 9 that a high percentage of study participants experience medium to high barriers in using smartphones for professional needs. School librarians from Australia, Hong Kong and UK mostly agree that smartphone screen is too small and that the small screen makes it difficult to read and type. Reading from smartphone screen is a barrier for $91 \%$ of school librarians from Hong Kong while it is a barrier for around $60 \%$ of school librarians from Australia and UK. The small size of the smartphone keypad and screen are perceived as a barrier for smartphone use in some other studies as well (Bibby, 2011; Dukic et al. 2015). Other barriers for school librarians from all three locations are web pages that are not formatted for smartphones and too slow to load. School librarians from Hong Kong 
again complain on these two barriers more frequently than school librarians from Australia and UK. It would be interesting to explore barrier issues further to learn more about these different perspectives among study participants from Australia, Hong Kong and UK.

Table 9: Barriers in using smartphone for professional purposes

\begin{tabular}{|l|c|c|c|}
\hline \multicolumn{1}{|c|}{ High/medium barriers } & Australia & Hong Kong & UK \\
\hline Screen size is too small & $67 \%$ & $84 \%$ & $74 \%$ \\
\hline Reading is difficult & $63 \%$ & $91 \%$ & $60 \%$ \\
\hline Typing is difficult & $62 \%$ & $71 \%$ & $68 \%$ \\
\hline Web page is not formatted for smartphone & $70 \%$ & $80 \%$ & $64 \%$ \\
\hline Load time is slow & $55 \%$ & $77 \%$ & $63 \%$ \\
\hline
\end{tabular}

\section{Conclusion and recommendations}

The major finding of this study is that smartphones are widely accepted among school librarians in Australia, Hong Kong and UK and that they use smartphones regularly for their various daily needs and for work and professional learning. The study findings show that school librarians use their smartphones for communication with colleagues regarding various professional issues, and for information searching, mostly with search engines. Further, they us smartphones to brows, read, and view resources from the Internet and to participate in professional social networking activities. It is also found that school librarians frequently use smartphone to manage daily schedule, to make notes and to take pictures for recording learning materials.

Regarding differences in smartphone use among school librarians from Hong Kong, Australia and UK, the findings show that there are some differences in ways and frequency of smartphone use among between them. School librarians from Hong Kong use smartphones more frequent than their colleagues from Australia and UK. A possible explanation for this difference might be a younger age of study participants from Hong Kong that might have an influence on their behavior in smartphone use.

The findings of this study could prove beneficial to researchers to further explore smartphone adoption and usage pattern among library and information professionals and to develop some more extensive studies on wider and more balanced samples.

The major benefit of this study for practicing school librarians might be to get a better insight in potentials of smartphone technology for their own professional learning and advancement. 


\section{Limitation of the study}

The major limitation of this study is that it was conducted on a very small sample so the study findings have a limited application. More extensive studies on larger samples are recommended.

\section{References}

Aharony, N. (2013). Mobile Libraries: Librarians' and Students' Perspectives. College \& Research Libraries, 75(2), 202-217.

Bibby, S. (2011), "Do students wish to 'go mobile? An investigation into student use of PCs and cell phones", International Journal of Computer-Assisted Language Learning and Teaching, 1 (2), 43-54.

Bomhold, C.R. (2013). Educational use of smart phone technology: A survey of mobile phone application use by undergraduate university students. // Program: electronic library and information systems, 47(4), $424-436$.

Dresselhaus, A., \& Shrode, F. (2012). Mobile Technologies \& Academics: Do Students Use Mobile Technologies in Their Academic Lives and are Librarians Ready to Meet this Challenge? Information Technology and Libraries (Online), 31(2), 82-101.

Dukic, Z., Chiu, D. K.W. and Lo, P. (2015). Learning with smartphones: higher education students' experiences and practices. In Needham, G. and Ally, M. (eds.). M-Libraries 5: From devices to people. London: Facet Publishing.

Franko, O. I. and Tirrell, T. F. (2012). Smartphone app use among medical providers in ACGME training programs. Journal of Medical Systems, 36(5), 3135-3139.

Gikas, J. and Grant, M. (2013). Mobile computing devices in higher education: Student perspectives on learning with cellphones, smartphones \& social media. Internet \& Higher Education, 19, 18-26.

Johnson, A. C., El Hajj, S. C., Perret, J. N., Caffery, T. S., Jones, G. N., \& Musso, M. W. (2015). Smartphones in Medicine: Emerging Practices in an Academic Medical Center. Journal of medical systems, 39(1), 1-6. 
Kukulska-Hulme, A., Pettit, J., Bradley, L., Carvalho, A. A., Herrington, A.,Kennedy, D. M., and Walker, A. (2011). Mature students using mobile devices in life and learning. International Journal of Mobile and Blended Learning, 3(1), 18-52.

Murphy, A., Farley, H., Lane, M., Hafeez-Baig, A. and Carter, B. (2014).Mobile learning anytime, anywhere: what are our students doing? Australasian Journal of Information Systems, 18(3), 331-345.

North, D., Johnston, K., \& Ophoff, J. (2014). The use of mobile phones by South African university students. Issues in Informing Science and Information Technology, 11, 115138. Retrieved from http://iisit.org/Vol11/IISITv11p115-138North0469.pdf

O' Connor, F. (2010). Doctors warming up to mobile devices. Computerworld, 44(16), 4.

Pažur, I. (2014).Attitude of the Rudjer Boš kovic Institute's scientists to the small screen mobile devices library services, Library Hi Tech, 32 (4 ), 628 - 644.

Wang, Y.S., Wu, M.C. and Wang, H.Y. (2009). Investigating the determinants and age and gender differences in the acceptance of mobile learning. British Journal of Educational Technology, 40(1), 92-118.

Wu J, Chatfield AJ, Hughes AM, Kysh L, Rosenbloom MC. (2014). Measuring patrons' technology habits: an evidence-based approach to tailoring library services. Journal of Medical Library Association, 102(2), 125-129.

\section{Biographical note}

Dr. Zvjezdana Dukic holds a PhD in Library and Information Science from the University of Zagreb, Croatia. She worked in academic, special and school libraries in Croatia, United Kingdom and Hong Kong. She also taught courses in the area of library and information management at The University of Hong Kong. Presently she is a part-time lecturer at the Department of Information Sciences, University of Zagreb. Her research interests focus on application of new technologies in library services and users' education. She has been giving presentations in many international conferences, published papers in international journals and also received several international awards for her work in school libraries in Hong Kong. 
Librarianship) from the Charles Sturt University. She worked in schools and libraries in Singapore and Hong Kong for over 15 years and now she is the Head Librarian of Secondary of The ISF Academy in Hong Kong. She is also teaching courses in teacher-librarianship at The University of Hong Kong SPACE and presenting at conferences. 